\title{
The effect of soil coverage on the soil quality
}

\author{
Sári, Sz. ${ }^{1}$, Kappel, N. ${ }^{2}$, Sipos, B. Z. ${ }^{3}$ and Forró, E. ${ }^{4}$ \\ 1,2,3,4 Szent István University, Faculty of Horticultural Science \\ 1.4 Soil Science and Water Management Department \\ ${ }^{2}$ Vegetable- and Mushroom Growing Department \\ ${ }^{3}$ Fruit Science Department \\ 1118 Budapest, Villányi út 29-43., T: 372-6272 \\ E-mail: 'talj@omega.kee.hu, ${ }^{2}$ kappelnoemi@freemail.hu, \\ 3siposb@omega.kee.hu, ${ }^{4}$ eforro@omega.kee.hu
}

Summary: In this study we carried out experiments with soil samples originated from the Haschberg variety elderberry orchard and wildgrowing plants from Szigetcsép Experimental Farm.

During the examinations we wanted to know how the black polyethene foliar soil coverage influences the quality of soil and the distribution of different nitrogen forms.

We studied the individual covered (foliar soil coverage for every plant), the full covered (foliar soil coverage was laid in the rows) and the uncovered threatments.

During the experiments we pointed out that the foliar coverage influences the condition of the soil unfavourably. Because of the coverage there is less air flow in soils, the lack of oxygen leads to degradating of soil life and results humus materials of poor quality.

Key words: soil coverage, humification, anaerobic circumstances, degradation

\section{Introduction}

Soil coverage as an agricultural engineering process is employed in the horticultural production extensively because it influences the water- heat- and nutrient management of the soil favourably and it increases the development and growing of the plants (Nagy, 1977, Sipos, 1985, Tindall et al., 1990). In addition as an effect of soil coverage the leaching of nutrients (Losacio et al., 1985.) and the development of weeds are limited (Racskó, 2002).

We can grow any kinds of plants but during the technology of growing we have to know that the agricultural processes are employed by us how influence the soil properties. Those experiments which studying the effects of foliar soil coverage have spread out just a little for the analysis that the foliar soil coverage how influences the changing of the soil parameters which characterizing the condition of humus materials. The results of our experiments contribute to give a more complete view, how foliar soil coverage influences the soil condition.

From the point of view of life nitrogen has excellent significance although the $80 \%$ of air consists of nitrogen, this amount give just the $2 \%$ of the total nitrogen-reserve of earth. The residual $98 \%$ can be found in the solid earth's crust and soils and mostly occur bound to the organic materials of soils (Gyốri, 1984). But this form of nitrogen is not available directly for plants. The organic nitrogen forms convert to inorganic forms during the microbiological processes of ammonification and nitrification (Németh, 1996). The amount of the available nitrogen is controlled by the grade of mineralization. The grade of mineralization is influenced by several factors (climatic- and soil conditions). Nitrification takes place just under required circumstances it means optimal pH-value, temperature, moisture-content of soils and in the presence of aerobic bacteria which are working just in the presence of oxygen (Reddy et al., 1980). Under anaerobic circumstances nitrate reduction and denitrification take place resulting in the nitrogen losses of soils.

This statement agrees with the earlier results of our experiments (Forró, 1999). During these experiments we wanted to know that the different arrangements of containers how influence the condition of soil and plants. According to the results the available nitrogen content was the least at the pipe containers arrangement. It means the nitrogen content was the least where the soil was isolated from air with foliar coverage. It is resulted by the lacking of oxygen because of it the function of aerob microorganisms are limited and those microbiological processes dominate which result nitrogen losses. These experiments also showed that the lower amount of available nitrogen content did not always result lower yields but it always resulted lower quality crops ( Table I).

Henceforth nitrogen is an essential nutrient for plants, the constituent of proteins and other essential materials 
Table I The effect of the arrangement of containers to yield of pepper at Fehérözön variety

\begin{tabular}{|l|c|c|c|}
\hline $\begin{array}{l}\text { Arrangement } \\
\text { of containers }\end{array}$ & $\begin{array}{c}\text { Average yield } \\
\left(\mathrm{pc} / \mathrm{m}^{2}\right)\end{array}$ & $\begin{array}{c}\text { Average yield } \\
\left(\mathrm{kg} / \mathrm{m}^{2}\right)\end{array}$ & $\begin{array}{c}\text { Average fruit } \\
\text { weight }(\mathrm{g})\end{array}$ \\
\hline Lifted bed & 57 & 5.1 & 90 \\
Bund & 61 & 4.3 & 69 \\
Pipe container & 64 & 3.9 & 61 \\
Bed container & 57 & 3.9 & 67 \\
\hline
\end{tabular}

(chlorophyll, vitamins). First of all it takes an effect the vegetative development of plants and has an influence on the changing of the quantity- and qualiy of crops (Novoa et al., 1981, Stevenson, 1982, Terbe, 1997).

The examined plant of our experiment was Haschberg variety elderberry (Sambucus nigra L). The curing effect of elderberry was known for centuries. Nowadays the using of elderberry as a colouring agent in food industrial products outdoes its employing as a medicinal plant.

The growing of elderberry have started since just several decades. In Europe only from the seventies have started its planting in a larger scale. In Hungary the annual yield is considerable 20000-25000 t/year but mostly it is originated from collecting. At present the area of the Haschberg variety elderberry orchards is about 2000 ha. The significance of the cultivation of elderberry increases continuously because the collected elderberry does not satisfy the requirements of processing industry (KSH, 2001, Sipos, pers. comm., 2003).

In nature we can see elderberry in skirts of the forest, areas with rubbish, in such areas where the nitrogen- ang organic matter-content of soils increased significantly because of some reasons (Porpáczyné \& Porpáczy, 1987). First of all we have to provide high nitrogen-content of soils during the cultivation. Elderberry requires a lots of nitrogen because it forms a lot of crops from year to year and connecting it has a lot of shoots from year to year, too (Schmidt, 1987).

\section{Method and material}

The experiment with Haschberg variety elderberry orchard was set up in the spring of 1998 at the Szigetcsép Experimental Farm of the University of Horticulture and Food Industry by the Department of Fruit Science. Joining to this experiment the Soil Science and Water Management Department carried out pedological and agrochemical examinations.

During the examinations we wanted to know how the black polyethene foliar coverage influences the quality and utilization of soils and the uptake of nutrients (mainly nitrogen). As a comparison we examined the soil of wildgrowing elderberries.

We studied the control, the individual covered (foliar soil coverage for every plant), the full covered (foliar soil coverage was laid in the rows) and the uncovered treatments. The plants of the individual covered, the full covered and the uncovered treatments received $4 \mathrm{dcg} /$ plant Agroblen fertilizer at the time of planting.

To carry out the pedological examinations we have taken soil samples in three times a year (between April and September in 1999. and 2000.) - in the period of the shoot developing, flowering and harvesting - from the orchard and wild-growing plants. Because of the main parts of the roots are located in the upper $10-20 \mathrm{~cm}$ depth layer of soils, the depth of soil sampling was the $0-20 \mathrm{~cm}$ depth soil layer, too. During soil sampling we have taken 4 soil samples from each treatment. The treatments were changed from one row to another (we have taken one-one sample from the beginning and at the end of the row and two samples from the middle of the row), at the publishing we counted means from the measured data.

We determined the moistness-content, the $\mathrm{pH}$ (in $\mathrm{H}_{2} \mathrm{O}$ and $\mathrm{KCl}$ ), the lime-content, the total humus-content $(\mathrm{H} \%)$, the quality of humus ( $\mathrm{Q}$ value), the hydrolizable nitrogencontent and the soluble potassium and phosphorus content in soil samples.

We carried out the laboratory analysis of soil samples according to the book of Buzás (1998).

As a counted value we published the value of $K$ coefficient which indicates the stability of humus materials $(\mathrm{K}=\mathrm{Q} / \mathrm{H} \%)$, and the value of the environmental protection capacity of soils (EPC), this value indicates the agrochemical utilization of soils. The EPC value makes possible the complex valuation of the condition of humus materials and this value shows the best the differences between natural and artificial soils.

$$
\begin{gathered}
E P C=D H \% Q, \\
\text { (Hargitai, 1983, Forró-Némethy, 1999) }
\end{gathered}
$$

$\mathrm{D}$ indicates the depth of the examined soil layer in $\mathrm{cm}$, $\mathrm{H} \%$ indicates the humus content of soils and Q indicates the quality of humus materials.

The area of Szigetcsép belongs to those climatic zone where the summer is warm, dry, temperately hot the changing of temperature is extreme and there is just very little precipitation. Its soil was formed on calciferous bedrock, its $\mathrm{pH}$ is slightly alkaline, it is a sandy soil with a low humuscontent (Table 2). According to its climatic and soil conditions this area is not suitable for black elderberry growing.

\begin{tabular}{|c|c|c|c|c|c|c|c|c|c|}
\hline Soil depth $(\mathrm{cm})$ & $\mathrm{pHH}_{2} \mathrm{O}$ & $\mathrm{pHKCl}$ & $\mathrm{CaCO}_{3} \%$ & $\mathrm{~K}_{\mathrm{A}}$ & Moisture content \% & $\mathrm{H} \%$ & Q & $\mathrm{K}$ & EPC \\
\hline $0-20$ & 7.95 & 7.63 & 4.4 & 29 & 8.6 & 0.8 & 0.9 & 1.3 & 18 \\
\hline $20-40$ & 8.01 & 7.71 & 2.5 & - & 10.1 & 0.6 & 1.9 & 3.2 & 30 \\
\hline $40-60$ & 8.21 & 7.75 & 3.3 & - & 13.6 & 0.4 & 1.3 & 1.5 & 12 \\
\hline
\end{tabular}

Table 2 The data of soil analysis of the soil type which characterizing the area 


\section{Results}

The $1-4$ steps of hydrolizable nitrogen content give those nitrogen amount which are available for plants. According to our results the amount of the available nitrogen have not changed among the treatments. It showed a little higher amount in the soil of wild-growing plants.

When we examined the amount of potentially available nitrogen-content (5 step), we found that sandy soils did not provide significant nitrogen reserves. The amount of potentially available nitrogen was twice as much in the soil of wild-growing plants than in the soil of the orchard (Table 3).

Table 3 The nitrogen-content in the soil of the orchard and the soil of wild-growing plants $(\mathrm{Nmg} / 100 \mathrm{~g}$ soil) and the proportion of different nitrogen forms 1999. IX. 11.

\begin{tabular}{|l|c|c|c|c|c|c|c|}
\hline Steps of hydrolysis & 1. & 2. & 3. & 4. & $1-4$. & 5. & 6. \\
\hline Control & 6.1 & 4.7 & 1.1 & 1.4 & 13.1 & 6.3 & 1.9 \\
Individual covered & 4.4 & 3.8 & 1.1 & 1.1 & 10.1 & 5.1 & 1.7 \\
Full covered & 5.5 & 4.8 & 1.1 & 1.1 & 12.6 & 5.8 & 1.7 \\
Uncovered & 4.6 & 3.9 & 1.2 & 1.1 & 10.8 & 6.1 & 1.8 \\
Wild-growing plants & 8.8 & 5.3 & 1.6 & 1.4 & 17.2 & 13.9 & 3.1 \\
\hline
\end{tabular}

In connection to the total amount humus quantity we found that in those plots where soil coverage were employed the conditions of humification were more disadvantageous and the total humus content of soils were lower (Table 4).

Table 4 The changes of total humus content $(\mathrm{H} \%)$, quality of humus (Q value) and EPC value at the different treatments and wild-growing plants 1999.06.06

\begin{tabular}{|l|c|c|c|c|c|}
\hline & Control & $\begin{array}{c}\text { Individual } \\
\text { covered }\end{array}$ & $\begin{array}{c}\text { Full } \\
\text { covered }\end{array}$ & Uncovered & $\begin{array}{c}\text { Wild-grow } \\
\text { plants }\end{array}$ \\
\hline $\mathrm{H} \%$ & 0.7 & 0.6 & 0.6 & 1.1 & 1.1 \\
$\mathrm{Q}$ & 1.3 & 1.7 & 1.2 & 1.1 & 0.5 \\
$\mathrm{EPC}$ & 18 & 20 & 16 & 30 & 14 \\
\hline
\end{tabular}

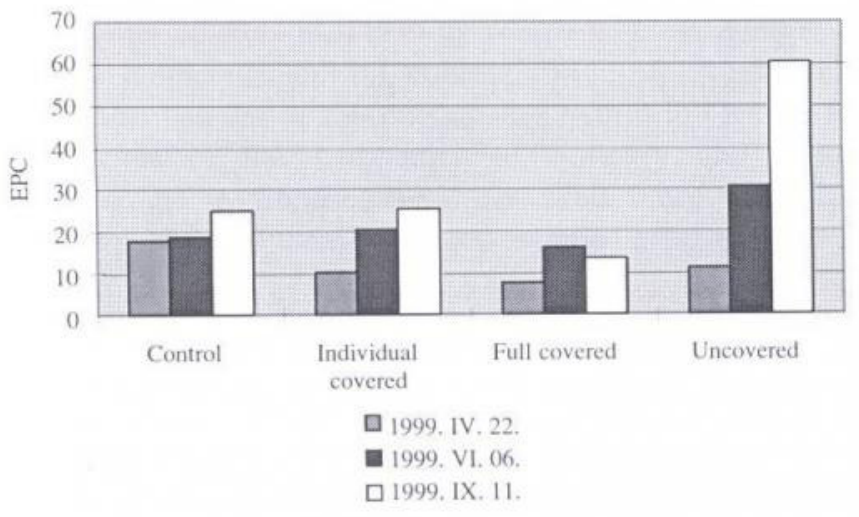

Figure 1 The changing of EPC values at different threatments
The Q value (which indicates the quality of humus) showed higher amount in case of the individual covered plots than at the full covered plots and showed much more fluctuation where coverage were employed (Table 4). The Q values especially increased at uncovered treatment while at the control treatment the quality of humus was the best in the $20 \mathrm{~cm}$ depth of soil (Table 2).

The changing of humus quality effects the utilization of soils. If we examine the changing of EPC (Environmental Protection Capacity) values we found that there were a significant difference between plots where soil coverage were employed and where soil coverage was missing. The utilization of soils increased at the biggest rate at the uncovered treatment ( Table 4, Figure I)

\section{Discussion}

According to our results we found that the available nitrogen-content of soils did not give significant difference at the different treatments.

According the results of potentially available nitrogencontent we found that the soil of the orchard did not provide nitrogen reserves but in the soil of wild-growing plants the nitrogen reserves were twice as high. It can be explained by the more intensive organic matter supply in the soil of wildgrowing plants.

The conditions of humification were more disadvantageous at soil covered treatments because when we covered the soil we interfered soil life. Under this kind of circumstances the vertical movements of living organisms and material were incomplete besides soil coverage effected oxygen-deficiency. These processes lead to the degradation of soil life and through of it effect disadvantageously to the conditions of humification.

The $Q$ value which indicates the quality of humus was higher at individual covered plots than at full covered plots because at individual covered plots the horizontal airflow was realized.

The changing of the quality of humus material influenced the utilization of soils. At soil-covered plots the EPC values increased in less rate than at uncovered treatments. According to these results we found that soil coverage effected disadvantageously the condition of soils.

According to soil analysis data characterizing the humus condition of soils we found that the effect of soil coverage to humus condition was not favourable because it limits airflow and out of this the role of the anaerobic processes increased in soils.

Elderberry demands soil coverage in the initial period of its development because in this way plants are rooting more security and we do not have to fear that roots will be hurt during mechanical weed control. We suggest employing just individual coverage. In this case the airflow has better conditions (because the coverage surface is smaller) and we have to buy less foliar to the covering it causes considerable saving, mainly in case of a large orchard. 


\section{Acknowledgement}

This research was supported by the Hungarian Scientific Research Fund (OTKA T 34644)

\section{References}

Buzás, I. (szerk.) (1988): Talaj- és agrokémiai vizsgálati módszerkönyv 2. A talajok fizikai - kémiai és kémiai vizsgálati módszerei Mezốgazdasági Kiadó, Budapest

Forró, E. (1999): A termésminốség biztosításának lehetôségei fólia alatti termesztésben mesterséges talajokban és közegekben. Agrárjövổnk alapja a minốség 419-423. XLI. Georgikon Napok Keszthely Forró, E. \& Némethy, A. (1999): Distribution of $\mathrm{N}$ forms and their changes in soils of natural areas. $10^{\text {th }}$ Nitrogen Workshop, 1: 15 .

Gyôri, D. (1984): A talaj termékenysége Mezôgazdasági Kiadó, Budapest

Hargitai, L. (1983): A talajok környezetvédelmi kapacitásának meghatározása humuszállapotuk alapján. Agrokémia és Talajtan 32: $360-364$.

Központi Statisztikai Hivatal (2001): Szôlô- és gyümölcsös ültetvények összeírása (Elổzetes adatok). KSH Budapest

Losacio, S. J., Fiskell, D. A., Graetz, D. A. \& Hanck, R. D. (1985): Nitrogen accumulation by peppers as influenced by mulch and time of fertilizer application. Journal Amer. Soc. Hort. Sci. 110: 325-328.
Nagy, J. (1977): Fólia a kertben - A talajtakarás Kertészet és Szốlészet, 26: 4.

Németh, T. (1996): Talajaink szervesanyag- tartalma és nitrogénforgalma MTA Talajtani és Agrokémiai Kutató Intézete, Budapest Novoa, R. \& Loomis, R. S. (1981): Nitrogen and plant production. Plant and Soil 58: 1-3.

Porpáczy, A.-né \& Porpáczy, A. (1987): A bodza Kertészet és Szốlészet, $36(9): 4$.

Racskó, J. (2002): Talajtakarás a zöldség- és gyümölcstermesztésben. Biokultúra 6: 23-25.

Reddy, K. R., Patrick, W. H. JR. \& Philips, R. E. (1980): Evaluation of selected processes controlling nitrogen loss in a flooded soil. Soil Science Soc. Amer. J., 44 (6): 1241-1246.

Schmidt, J. (1987): Holunderanbau Stocker Verlag, Graz.

Sipos, B. Z. (1985): Mũanyagtermékek a gyümölcstermesztésben in Somos A., Filius I., Turi I. Mủanyagok a kertészetben Mezổgazdasági Kiadó, Budapest

Sipos, B. Z. (2003): personal communication.

Stevenson, F. J. (1982): Humus Chemistry - Genesis, composition, reactions A Wiley - Interscience Publication, University of Illionis

Terbe, I. (1997): A leggyakoribb hiánybetegségek és környezeti károsodások. Agrofórum. 1 (8): 27-29.

Tindall, J. A., Mills H. A. \& Raddiffe D. E. (1990): The effect of root-zone temperature on nutrient uptake of tomato. Journal Plant Nutr. 13: 939-956. 